\title{
MEDIA GARIS BILANGAN UNTUK MENINGKATKAN KEMAMPUAN SISWA MENGHITUNG OPERASI BILANGAN BULAT
}

\author{
Muhammad Sholahuddin Arif ${ }^{1)}$, Kholifah ${ }^{2)}$ \\ ${ }^{1), 2)}$ Universitas Ronggolawe \\ E-mail: msholahuddinarif23@gmail.com ${ }^{1)}$ \\ kholifah_ikip@unirow.ac.id ${ }^{2)}$
}

\begin{abstract}
The objective of this study to describe the use of numbers board media. It is used to improve the learning outcomes of the mathematics subject which calculate the Additional Operation and Integer Reduction material, especially at remote rural schools. In addition, the purpose is to determine the extent of the effectiveness of the use of numbers board media to improve the mathematics achievement which calculates the Additional Operation and Integer Reduction material in class IV SDN Bektiharjo VI Kecamatan Semanding. The data that used were obtained from the test results and observations of the students in the process of the teaching and learning by the number of 24 children. The result of this study that was obtained by the observation from the teacher to the students on the learning process has increased in each cycle. In the first cycle of the observation has the total score is 52 and it has increased on the second cycle which has the total score is 69. Furthermore, the result of the students' mathematic subject which the school standard value of SDN Genaharjo VI is 70 was also increased from the first cycle of the total value in 1650 with an average of 68.7 and the second cycle of the total value in 2030 with an average of 84.5 .
\end{abstract}

Keywords: Mathematics, Numbers Board Media, Remote Rural Schools, Additional Operation and Integer Reduction

\section{PENDAHULUAN}

Salah satu tugas utama seorang guru dalam mewujudkan tujuan-tujuan pendidikan di sekolah adalah mengembangkan strategi belajar mengajar secara efektif. Pengembangan strategi belajar mengajar ini bertujuan untuk menciptakan kondisi-kondisi yang dapat mempengaruhi kehidupan peserta didik sehingga mereka dapat belajar dengan menyenangkan dan dapat meraih prestasi belajar yang memuaskan. Menyelenggarakan kegiatan belajar mengajar yang berlangsung secara efektif, merupakan pekerjaan yang bersifat kompleks dan menuntut kesungguhan dari seorang guru.
Pemahaman atas perkembangan peserta didik sekaligus dengan keunikannya akan sangat dibutuhkan guru dalam mengidentifikasi rentang perilaku yang cocok (perilaku pada diri anak) sebagai tujuan yang dapat dicapai dalam pengajaran, kegiatan dan pengalaman belajar bagi kelompok usia tertentu, serta sistem evaluasi yang hendak digunakan. Pemahaman akan dimensi individual yang mengakui adanya keragaman latar belakang keluarga peserta didik, maka seorang guru dengan sendirinya memandang penting keterlibatan aktif orang tua baik sebagai sumber ataupun sekaligus pembuat keputusan mengenai ketepatan perlakuan atau pelayanan individual bagi pendidikan anak. 
Dengan memerhatikan segi individualitas dan karakteristik anak usia sekolah dasar serta berbagai dimensi perkembangannya, maka seorang guru tidak asal suka begitu saja mengembangkan pengajaran di sekolah atau kelasnya. Seorang guru dituntut dalam mengembangkan sistem pengajarannya, tidak menyimpang dari prinsip-prinsip psikologis yang ada. Kenyataan ini, menjadi alasan yang kuat mengapa sistem pengajaran yang dikembangkan guru diharapkan akan semakin dapat melayani kebutuhan peserta didik individual (individually guided education) dan pengajaran itu benar-benar menjadi menarik dan bermakna bagi anak.

Sehubungan dengan pelaksanaan tugas di atas, yakni mengembangkan strategi belajar mengajar yang efektif, seorang guru membutuhkan dasar pengetahuan yang cukup mengenai pendekatan strategi belajar mengajar yang berorientasi pada perkembangan peserta didik. Lebih lanjut, kegiatan belajar mengajar bagi anak usia sekolah dasar mempunyai arti dan tujuan tersendiri. Hal ini berkaitan erat dengan ciri-ciri atau karakteristik anak yang bersangkutan. Seorang guru sekolah dasar sewajarnya memahami bahwa komponen anak merupakan komponen terpenting dalam proses pengajaran. Oleh karena itu, proses pengajaran itu harus diciptakan atas dasar pemahaman siapa dan bagaimana anak tumbuh dan berkembang. Dengan kata lain, kegiatan belajar mengajar yang secara praktis dikembangakan guru di sekolah dasar dituntut untuk berorientasi pada perkembangan anak secara tepat.

Pada mata pelajaran matematika terutama pada pembelajaran operasi penjumlahan dan pengurangan bilangan bulat seperti yang tercantum dalam kurikulum 1994 maupun kurikulum
2006 mulai diperkenalkan pada siswa sekolah dasar di kelas IV (empat) pada dasarnya belum semua peserta didik mampu menghitung operasi penjumlahan dan pengurangan bilangan bulat dengan baik dan benar, terutama pada sekolah-sekolah yang berada di pelosok pedesaan. Hal ini disebabkan oleh karena karakteristik lingkungan dan masyarakat yang ada di daerah pedesaan yang mendukung terhadap tujuan dari pendidikan itu sendiri. Dan juga model pembelajaran serta strategi belajar mengajar yang diterapkan dan digunakan oleh guru kurang bisa dipahami oleh siswa sehingga siswa sangat lambat dalam menerima materi pembelajaran terutama pembelajaran operasi penjumlahan dan pengurangan bilangan bulat pada mata pelajaran matematika di kelas IV. Hal itu pulalah yang terjadi di kelas IV SDN Bektiharjo VI Kecamatan Semanding Kabupaten Tuban.

Dengan demikian, untuk mengatasi masalah tersebut, seorang guru di tuntut untuk melakukan berbagai cara dengan menggunakan berbagai strategi belajar mengajar yang tepat dan sesuai dengan karakteristik anak, salah satunya adalah dengan menggunakan media papan bilangan yang dapat meningkatkan kemampuan operasi penjumlahan dan pengurangan bilangan bulat pada anak.

Melalui penggunaan media garis bilangan diharapkan kemampuan siswa dalam operasi penjumlahan dan pengurangan bilangan bulat pada mata pelajaran matematika akan meningkat, sehingga dengan prestasi anak dalam mata pelajaran matematika akan meningkat pula. Dengan media tersebut, diharapkan siswa akan dapat segera mengatasu kekurangannya, sehingga kemampuan menghitung operasi penjumlahan dan pengurangan bilangan 
bulat pada mata pelajaran matematika mereka meningkat dan tentu saja hal tersebut akan meningkatkan pada prestasi belajarnya.

\section{METODE PENELITIAN}

Pengambilan data dilakukan pada siswa kelas IV SDN Bektiharjo VI Semanding Tuban secara observasi langsung. Sasaran observasi berupa pengamatan pengolahan pembelajaran untuk mengamati kesiapan guru dalam pembelajaran. Observasi berfungsi untuk mendokumentasikan pengaruh terkait bersama prosesnya (Madya, 2006). Yang kemudia dites sebagai indikator keberhasilan siswa. Menurut Arikunto (2001) tes adalah serentetan pertanyaan atau latihan yang digunakan untuk mengukur keterampilan, pengetahuan intelegensi, kemampuan, atau bakat yang dimiliki individu atau kelompok. Tes ini dilakukan bertujuan untuk mengukur siswa ditinjau dari aspek kognitif dengan pemberian tes akhir pembelajaran. Adapun tes tersebut berupa lembar observasi yang diperlukan guru dalam kegiatan refleksi sebagai hasil tindak lanjut tentang pencapaian berhasi tidaknya tujuan pembelajaran pada setiap siklus. Selama proses belajar mengajar berlangsung, terdapat kriteria pendataan nilai guru, (1) Tidak Baik $=18-31$, (2) Kurang Baik $=31-44$, (3) Cukup Baik $=44-$ 57, dan (4) Baik $=57-70$. Selain itu, pada mata pelajaran matematika memiliki nilai KKM yakni 70. Jika nilai di atas $\mathrm{KKm}$ maka siswa telah tuntas dalam mata pelajaran tersebut dan jika di bawah $\mathrm{KKm}$ maka siswa tersebut perlu adanya tindak lanjut.

\section{Pembelajaran Matematika di Sekolah Dasar (SD)}

Hakikat pembelajaran matematika di SD menurut Arifin (2009) menyatakan bahwa "ungkapan yang digunakan untuk merumuskan hakikat matematika harus benar-benar merupakan ungkapan yang mempresentasikan seluruh bidang dan obyek kajian yang telah dikembangakan, sedang dikembangkan, atau yang akan dikembangkan dalam ilmu matematika". Tidak sedikit ahli matematika yang berhasil merumuskan hakikat matematika. Hal ini disebabkan, kegiatan mengajajar bukan sekedar menyangkut persoalan penyampaian pesan-pesan dari seorang guru kepada para peserta didik. Hal ini sebenarnya menyangkut persoalan bagaimana guru pembimbing dan melatih peserta didik untuk belajar diperlukan kemampuan professional dari guru.

Untuk memperlancar proses belajar mengajar seorang guru harus paham dan menguasi karakteristik peserta didik. Morgan dan King (1986) merumuskan pengertian belajar yang modern sebagai setiap perubahan tingkah laku yang relative tetap dan terjadi sebagai hasil latihan dan pengalaman. Definisi ini memuat dua unsur penting dalam belajar yaitu, pertama belajar adalah perubahan tingkah laku, dan kedua perubahan yang terjadi adalah karena latihan atau pengalaman. Sedangkan, Davis (1971) mengungkapkan bahwa pengertian belajar sebagai suatu aktifitas professional yang memerlukan keterampilan tingkat tinggi dan mencangkup pengambilan keputusan.

Singkat cerita, strategi belajar mengajar pada dasarnya mencangkup empat hal utama, yaitu (1) penetapan tujuan pengajaran, (2) pemilihan sistem pendekatan belajar mengajar, (3) pemilihan dan penetapan prosedur, metode, dan teknik belajar mengajar, dan (4) penetapan kriteria keberhasilan proses belajar mengajar dari evaluasi 
yang dilakukan (Twelker dkk., 1972). Strategi belajar mengajar pada matematika itu erat kaitannya dengan minat belajar siswa untuk memahami materi. Sehingga siswa suasana pembelajaran matematika menjadi suasana belajar yang menyenangkan (joyful learning).

Materi matematika yang dipelajari siswa Sekolah dasar yang diminati siswa telah dibatasi dalam lingkup bahan kajian inti sesuai ketentuan dalam Garis Besar Program Pengajaran (GBPP) oleh Tim Peneliti FMIPA ITB (2002) merumuskan pertama, pengenalan suatu konsep hendaknya dilakukan dengan menggunakan masalah. Kedua, Masalah yang disajikan sedapat-dapatnya berupa masalah yang memiliki makna dalam kehidupan sehari-hari. Ketiga, Operasi penjumlahan dan pengurangan bilangan bulat merupakan bagian yang tidak terpisahkan dari aspek pembelajaran setiap materi, kemampuan memahami materi harus mencangkup kemampuan menyelesaikan operasi penjumlahan dan pengurangan bilangan bulat. Keempat, dalam memberikan contoh suatu konsep, hendaknya ragam contoh cukup luas, sehingga siswa tidak membangun persepsi yang sempit tentang konsep yang dipelajari. Kelima, terdapat beberapa tahapan dalam mengenalkan suatu konsep, yaitu tahapan konkret, dilanjutkan semi konkret, dan diakhiri dengan tahapan abstrak.

\section{Media Garis Bilangan}

Salah satu media pembelajaran matematika bagi siswa SD adalah menggunakan media garis bilangan. Media garis bilangan adalah sebuah alat peraga atau suatu media yang digunakan dalam proses belajar mengajar pada mata pelajaran matematika dengan memanfaatkan karton atau papan kayu atau juga membuat kotak-kotak di lantai menyerupai papan yang tiap permukaannya diberi tulisan berupa lambang bilangan bulat yang digunakan untuk memperagakan cara menghitung operasi penjumlahan dan pengurangan bilangan bulat pada mata pelajaran matematika SD. Hal ini dilakukan untuk mempermudah pemahaman siswa terhadap pembelajaran operasi penjumlahan atau pengurangan bilangan bulat pada mata pelajaran matematika.

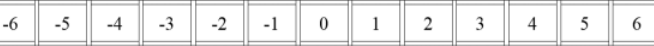

Gambar 1. Contoh media garis bilangan

Pada umumnya siswa akan lebih cepat bosan jika dalam proses belajar mengajar hanya menggunakan model pembelajaran ceramah. Sehingga, siswa merasa kesulitan untuk mengingat dan memahami materi pembelajaran yang disampaikan. Bagi anak yang tingkat kecerdasannya tinggi tentu saja tidak ada masalah, akan tetapi bagi anak bagi anak yang kurang cerdas atau cara berfikirnya lambat akan sangat kesulitan dan kurang bisa memahami terhadap materi yang disampaikan.

Tabel 1. Aturan Main dalam Penggunaan Media Garis Bilangan

\begin{tabular}{cc}
\hline Operasi/ Bilangan & Arah \\
\hline Penjumlahan & Maju/Tetap \\
Pengurangan & Balik Kanan \\
Bulat Positif & Maju \\
Bulat Negatif & Mundur \\
\hline
\end{tabular}

Contoh penerapan media garis bilangan dalam menghitung operasi penjumlahan dan pengurangan bilangan bulat. Misalkan $3+(-2)=\ldots$.

Berdasarkan contoh soal tersebut, terdapat dua bilangan bulat dan satu operasional yakni bilangan bulat positif (3), bilangan bulat negative (-2) dan operasional penjumlahan dan cara 
pengoperasiannya adalah sebagai berikut :

1. Posisi awal pada nol menghadap ke kanan

\begin{tabular}{|l|l|l|l|l|l|l|l|l||l||l|l|l|}
\hline & Il \\
\hline \hline-6 & -5 & -4 & -3 & -2 & -1 & 0 & 1 & 2 & 3 & 4 & 5 & 6 \\
\hline
\end{tabular}

Gambar 2. Posisi awal siswa

2. Karena $+($ ditambah $)$ arah tetap

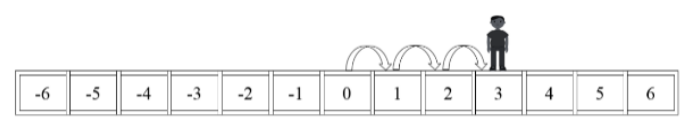

Gambar 3. Posisi tambah tiga

3. Karena (-2) merupakan bilangan bulat negatif maka mundur 2 langkah

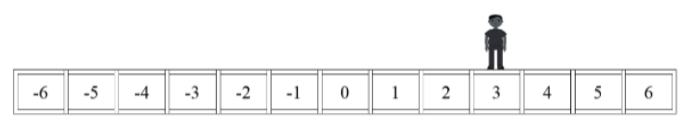

Gambar 4. Posisi ditambah dengan bilangan bulat -2

4. Jadi hasil dari penjumlahan bilangan bulat positif dan bilangan bulat negative dari $3+$ (-2) adalah 1

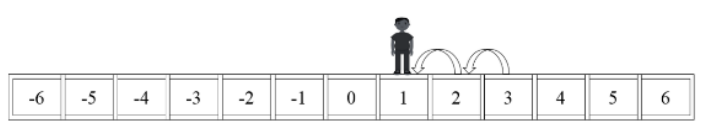

Gambar 5. Posisi hasil akhir

\section{Prosedur Penelitian (Siklus)}

Menurut Kemmis dan Mc Taggart (1988 prosedur untuk melaksanakan penelitian tindakan kelas terdiri atas, (1) Perencanaan, (2) Pelaksanaan Penelitian, (3) Obeservasi, dan (4) Refleksi. Sebelum pelaksanaan penelitian, diperoleh hasil pembelajaran belajar belajar mengajar sebelum digunakannya media garis bilangan untuk menghitung operasi penjumlahan dan pengurangan bilangan bulat.
Pembelajaran ini dinamakan Pra Siklus. Barulah setelah itu, dilakukan tindakan pembelajaran Siklus I dan Siklus II, yang mana atas siklus I dan siklus II yang meliputi perencanaan tindakan, pelaksanaan tindakan, observasi, dan refleksi.

Adapun tahapan siklus I diantaranya, pertama : menetapkan SK, $\mathrm{KD}$, dan indikator tujuan pembelajaran. Kedua : menyusun tujuan pembelajaran. Ketiga menyusun rencana pelaksanaan pembelajaran. Keempat, mempersiapkan media papan bilangan. Kelima, menyiapkan topik yang akan diteliti. Keenam, menyiapkan instrumen penelitian berupa lembar observasi dan Lembar Kerja Siswa yang digunakan untuk mengetahui keterlaksanaan dan ketercapaian tindakan. Selain itu, pada Siklus I, diidentifikasi masalah dengan cara menyusun perangkat pembelajaran, diantaranya:

1. Merumuskan tujuan pembelajaran matematika pokok bahasan menghitung operasi penjumlahan dan pengurangan bilangan bulat.

2. Menetapkan strategi pembelajaran dengan alat peraga/media garis bilangan.

3. Menyusun instrument pengamatan aktifitas belajar, pedoman penilaian hasil belajar, dan refleksi.

Selanjutnya, pada Siklus II yang mana merupakan pembelajaran perbaikan dari siklus I jika masih ada kekurangan, diterapkan cara menyusun perangkat pembelajaran yang sama dengan Siklus I. Hanya saja bedanya dengan Siklus I, Siklus II menggunakan metode Live Action perseorangan/ masing-masing siswa supaya siswa dapat lebih mudah memahami penggunaan media papan bilangan dan mudah menerapkannya dalam 
menghitung operasi penjumlahan dan pengurangan bilangan bulat.

\section{HASIL PENELITIAN DAN PEMBAHASAN}

\section{Hasil Observasi}

Berdasarkan pengalaman dan pengamatan di kelas, khusunya kelas IV SDN Bektiharjo VI Tuban, ditemukan siswa tampak mengalami kesulitan ketika harus menghitung operasi penjumlahan dan pengurangan bilangan bulat. Siswa tidak tahu bagaimana cara menghitung dengan mudah dan menyenangkan, sehingga pelajaran matematika tidak menjadi suatu momok atau hal yang menakutkan bagi siswa ketika berada di sekolah.

Data nilai pra siklus diambil sebelum menggunakan media garis bilangan dalam pembelajaran di kelas IV mata pelajaran matematika materi menghitung operasi penjumlahan dan pengurangan bilangan bulat SDN Bektiharjo tersebut adalah dengan nilai rata-rata masih di bawah KKM yakni 70. Berdasarkan jumlah nilai siswa pada tes formatif pra siklus adalah 1430 dengan nilai rata-rata 59,5. Jadi dapat disimpulkan bahwa kegiatan belajar mengajar awal sebelum siklus memperoleh hasil yang kurang memuaskan karena nilai rata-rata masih dibawah KKM sehingga perlu dilakukan kegiatan perbaikan pada siklus.

Tindakan yang dilakukan pada siklus I adalah pembelajaran Matematika materi menghitung operasi penjumlahan dan pengurangan bilangan bulat dengan menggunakan media garis bilangan. Pertama-tama menyiapkan media garis bilangan untuk menghitung operasi penjumlahan dan pengurangan bilangan bulat, siswa melihat soal, kemudian menghitung menggunakan media papan bilangan di depan kelas secara bergantian. Dengan menggunakan media garis bilangan yang tersedia siswa menjawab soal yang sudah tersedia.

Berdasarkan tindakan yang telah dilakukan dihasilkan sebuah data yang kemudian dianalisis dan diolah. Jika ketercapaian hasil pembelajaran menunjukkan kemajuan maka penelitian hanya dilaksanakan melalui siklus I. Namun jika masih ada kekurangan maka hasil diperbaiki pada siklus II. Pelaksanaan kegiatan belajar mengajar untuk siklus I dilaksanakan hari rabu tanggal 24 april 2013 pada semester II di tahun pelajaran 2012/2013 dengan jumlah siswa 24 siswa kelas IV SDN Bektiharjo VI Tuban. Pada tahap ini dilaksanakan kegiatan pembelajaran sesuai dengan rencana perbaikan yang telah disusun.

Pada siklus I jumlah total nilai adalah 52 masuk kriteria $3=$ cukup baik dengan nilai rata-rata 2,8 . Jadi dapat disimpulkan aktifitas guru dan siswa sudah seimbang dan sesuai dengan perencanaan perbaikan pembelajaran pada siklus I. Kegiatan belajar mengajar pada siklus I sudah mengalami peningkatan tetapi masih kurang memuaskan karena nilai rata-rata masih dibawah KKM yakni 68,7 dengan jumlah nilai siswa 1650. Dapat dikatakan hasil ini belum tuntas belajar sehingga perlu dilakukan perbaikan pada siklus selanjutnya.

Dari pemerolehan pengamatan pelaksanaan kegiatan belajar mengajar dari siklus I masih mendapat kekurangan sehingga perlu dilakukan revisi pada pelaksanaan berikutnya. Kemudian dilakukan dialog dengan guru tentang pemecahan masalah. Berdasarkan hasil diskusi, diperoleh 
solusi bahwa akan diterapkan metode Live Action perseorangan atau masingmasing siswa supaya siswa lebih mudah memahami penggunaan media papan bilangan dan mudah menerapkanya dalam menghitung operasi penjumlahan dan pengurangan bilangan bulat.

Pelaksanaan kegiatan belajar untuk siklus II dilaksanakan hari rabu tanggal 8 april 2013 pada semester II di tahun 2012/2013 dengan jumlah siswa 24 siswa. Pada tahap ini dilaksanaan kegiatan pembelajaran sesuai dengan rencana perbaikan yang telah disusun. Pada siklus II dengan total nilai 69 masuk kriteria $4=$ baik dan mengalami peningkatan dibanding siklus sebelumnya yakni nilai rata-rata 3,8 . Jadi dapat disimpulkan aktifitas guru dan siswa sudah seimbang. Hal ini sesuai dengan perencanaan perbaikan pembelajaran pada siklus II. Hasil penelitian menunjukkan bahwa jumlah siswa pada tes perbaikan siklus II adalah 2030 dengan nilai rata-rata 84,5. Dengan demikian, kegiatan belajar mengajar pada siklus II memperoleh hasil yang memuaskan karena nilai ratarata diatas KKM atau tuntas dalam belajar sehingga tidak perlu dilakukan perbaikan pada siklus selanjutnya.

\section{Penggunaan Media Garis Bilangan pada Aktifitas Guru dan Siswa}

Berdasarkan interpretasi hasil penelitian, diperoleh aktifitas guru dan siswa dalam proses pembelajaran Matematika materi menghitung operasi penjumlahan dan pengurangan bilangan bulat dengan menggunakan media garis bilangan mengalami peningkatan. Guru sangat terbantu dalan menjelaskan, menginformasikan dan memberikan pemahaman tentang kemampuan menulis karangan terhadap siswa. Siswa juga lebih aktif, terbimbing, termotivasi dan memahami materi menulis karangan. Hal ini dapat dilihat dari tabel aktifitas guru dan siswa dalam pembelajaran. Jumlah skor dan rata-rata tiap siklus pada aktifitas guru maupun siswa mengalami peningkatan yakni pada siklus I jumlah skor 52 dengan nilai rata-rata 2,8 dan siklus II jumlah skor 69 dengan nilai rata-rata 3,8.

\section{KESIMPULAN DAN SARAN}

Dari analisis data menggunakan metode Live action perorangan didapatkan hasil tes hasil belajar yang meningkat. Sehingga, penggunaan Media Garis Bilangan Bulat membantu siswa dalam meningkatkan kemampuan menghitung operasi penjumlahan dan pengurangan bilangan bulat mata pelajaran matematika, terbukti dengan menggunakan media garis bilangan dalam operasi penjumlahan dan penggunaan bilangan bulat mata pelajaran matematika kelas IV Bektiharjo VI kecamatan semanding kabupaten Tuban tahun pelajaran 2012/2013. Hal ini diketahui pada analisis pembahasan yang menyatakan nilai rata-rata tes hasil belajar mengalami peningkatan yaitu sebelum penelitian pra siklus dengan nilai ratarata 59,5, pada siklus I nilai rata-rata 68,7 dan kemudian siklus II nilai ratarata 84,5. Terlihat berdasarkan hasil pra siklus, siklus I, dan siklus II maka efektifitas pembelajaran matematika materi menghitung operasi penjumlahan dan pengurangan bilangan bulat menghasilkan data 68,7 (Siklus I) - 59,5 (Pra Siklus) $=9.2$ dan 84,5 (Siklus II) $68,7($ Siklus I) $=15.8$. Dengan demikian, menghitung operasi penjumlahan dan pengurangan bilangan bulat dengan menggunakan media garis bilangan dilihat dari siklus I dan siklus II mengalami peningkatan.

Namun demikian, guru yang melakukan pembelajaran di daerah 
pelosok harus terus berbenah diri dan inovatif dalam mengembangkan suatu system pengajaran dan pendidikan. Hal ini dilakukan agar dapat bersaing dengan lembaga pendidikan lainnya dalam menghasilkan lulusan siswa yang lebih berkualitas.

\section{DAFTAR PUSTAKA}

Arifin, Zainal. 2009. Metode Penelitian

Pendidikan. Surabaya: Lentera Cedikia.

Arikunto, Suharsini. 2001. Dasar-Dasar Evaluasi Pendidikan. Jakarta: Bumi Aksara.

Davis, IK. 1971. The Management of Learning. London: McGrawHill Book Company.

Kemmis,S dan Mc. Taggart, R. 1988. The Action Research Planner. Victoria : Deakin University Press.
Madya, Suwarsih. 2006. Penelitian Tindakan: Action Research. Bandung: Alfabeta.

Morgan, C.T. and King, R.A. 1986. Introduction to Psychology. New York: McGraw-Hill Book Company.

Tim ITB. 2002. Pengkajian Kurikulum dan Model Pembelajaran Mata Pelajaran Matematika. Rangkuman hasil penelitian yang diseminarkan dalam Seminar Nasional Direktorat TK dan SD dirjen dikdasmen Depdiknas di Jakarta.

Twelker dkk. 1972. The Systematic Development of Instruction. Stanford: ERIC Clearinghouse on Media and Technology. 